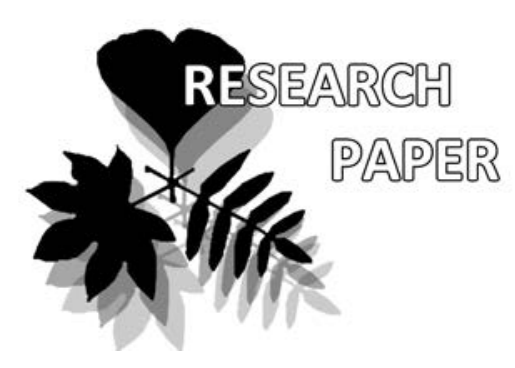

Ujjwal Layek ${ }^{1}$

e-mail: layekujiwal@yahoo.co.in

ORCID: 0000-0002-3169-1559

Arijit Kundu ${ }^{2}$

e-mail: ksubaikundu@gmail.com

Prakash Karmakar ${ }^{2 *}$

e-mail: prakashbot1973@gmail.com

${ }^{1}$ Department of Botany,

Rampurhat College, Birbhum, India

${ }^{2}$ Department of Botany \& Forestry,

Vidyasagar University, Midnapore, India

* corresponding author

Manuscript received: 13.06 .2020

Review completed: 05.08.2020

Accepted for publication: 08.08 .2020

Published online: 17.08.2020

\section{Floral ecology, floral visitors and breeding system of Gandharaj lemon (Citrus x limon L. Osbeck)}

\author{
Ujjwal Layek ${ }^{1}$ Arijit Kundu ${ }^{2}$ \& Prakash Karmakar ${ }^{2 *}$
}

\begin{abstract}
A B S T R A C T
We studied the floral ecology, floral visitors and breeding system of Citrus $\times$ limon in West Bengal, India. We calculated a coefficient of pollination deficit (D) and also estimated the values of 'relative pollinator service (RPS)' to determine primary pollinators of the plant species. The cultivar is fully self-compatible and produces protandric hermaphrodite flowers and male flowers with considerable amount of floral rewards. Several insects like honey bees, solitary bees, carpenter bees, flies and butterflies visited the flowers. Among those, primary pollinators were Halictus sp. and Nomia sp., and important secondary pollinators were Apis dorsata and Xylocopa fenestrata. Considering the visitors' group, the cultivar is principally pollinated by solitary bees. Besides diverse floral visitors, the cultivar showed medium pollination deficit $(\mathrm{D}=0.49)$ and resulting in low fruit-set. Furthermore, premature fruit abortion is also high in all pollination treatments which lead to a low fruit-set of this lemon variety in West Bengal.
\end{abstract}

Ke y w o r d s : pollination deficit, relative pollinator service, self-compatible, solitary bee

\section{P E 3 Ю M E}

Ааек, У., КунАУ, А., Кармакар, П. Экология цветения, посетители цветка и система размножения ГандхараАжского мимона (Citrus $\times$ limon L. Osbeck). Исследована экология цветения, режим посещений цветка и система размножения Citrus $\times$ limon в Западной Бенгалии, Индия. А^я определения первичных опылителей виАа мы рассчитали коэффициент Аефицита опыления (D), а также оценили значения «относительного вклада опылителей» (RPS). Сорту свойственно самоопыление, в результате которого появ яяются протандрические гермафродитные цветки и мужские цветки со значительным количеством тычинок. Ряд насекомых, таких как медоносные пчелы, одиночные пчелы, плотничьи пчелы, мухи и бабочки, посетил цветки. СреАи них первичными опылителями были Halictus sp. и Nomia sp., и важными вторичными опылителями были Apis dorsata и Xylocopa fenestrata. Установлено, что сорт в основном опыляется группой одиночных пчел. При всем разнообразии посетителей, сорт показал средний дефицит опыления $(\mathrm{D}=0,49)$ и, как следствие, низкое плодоношение. Кроме того, преждевременное прерывание развития плодов сохранялось при всех вариантах опыления, которые приводили к низкой урожайности этого сорта Аимона в Западной БенгаАии. КАючевые слова: дефицит опыления, относительный вклад опылителя, самоопыление, одиночная пчела

Переведено редколиегией
Sexual reproduction of flowering plants largely depends on successful pollination. During pollination, pollen grains transferred from the anthers to the receptive stigmas of conspecific flowers, which are again fulfilled either by abiotic and/or biotic factors (Ashman et al. 2004, GainesDay \& Gratton 2015). However, biotic pollinators serve better mode for pollen transfer than the abiotic, as they effect in targeted deposition of pollen among conspecifics. Again, variation in the abundance and availability of pollinators influences the reproductive success of plants. Floral biology (including flowering phenology and patterns) influence the quantity and quality of pollen dispersed during pollination through plant-pollinator interactions, leading to the deposition of self- and out crossed pollen on stigmas which in turn impacts over fruit and seed set (Ollerton et al. 2011). Thus, it is crucial to study phenological consistencies and pollinators to better understand the importance of floral biology on reproductive success (Kudo 2006, Elzinga et al. 2007).

Citrus is an economically important fruit crop of India. Most Citrus species produce a large number of flowers over the year. Floral load depends on several factors like age of the tree, type of cultivar, and environmental conditions (Monselise 1986). In spite of large number of flowers, only a small proportion developed into mature fruits (Erickson \& Brannaman 1960, Goldschmidt \& Monselise 1977, Zucconi et al. 1978, Agustí et al. 1982). The reasons are low fruit set due to inadequate pollination success, greater competition for carbohydrates (Hilgeman et al. 1967), water stress during the flowering periods (Koo 1967) and abscission of reproductive structures influenced by flowering intensity (Agustí et al. 1982). 
Citrus $\times$ limon (L.) Osbeck commonly known as 'Gandharaj lemon', is cultivated in many areas of West Bengal, India. The ellipsoidal yellow fruit is used for culinary and non-culinary purposes. Additionally, the large-sized fruits are highly flavored in comparison to other cultivars, therefore, have a greater demand with high market value. However, the yield (fruit-set) of this cultivar is very low for some unknown reasons. Thus, knowledge about pollination ecology vis-à-vis breeding system will be helpful to overcome the production related crisis in this variety of lemon.

We performed this study to ascertain the reason for low fruit set by looking into the floral ecology, breeding system and floral visitors of Citrus $\times$ limon. We focused on the following questions: (1) Does the ratio of hermaphrodite to male flower change across the flowering period? (2) Who are the effective pollinators of the lemon cultivar? (3) Is this cultivar self-incompatible? (4) Is there any pollination limitation at the study sites? (5) What is the extent of premature fruit abortion in this cultivar?

\section{MATERIAL AND METHODS \\ Study area}

The study was conducted at two sites namely, Bolpur $\left(23.6712^{\circ} \mathrm{N} 87.6919^{\circ} \mathrm{E}\right)$ in Birbhum district and Chandannagar town $\left(22.5153^{\circ} \mathrm{N} 88.2147^{\circ} \mathrm{E}\right)$ in Hooghly district of West Bengal, India during 2018-2020. We considered seven plants in Bolpur and five plants in Chandannagar for data collection.

\section{Floral ecology}

We observed the flowering period, flowering pattern, flower longevity, time of anthesis, and measured the dimensions (length and breadth) of floral parts. The flowering pattern is determined according to the types mentioned by Gentry (1974) and Opler et al. (1980). To determine the longevity of individual flower, we tagged inflorescences and flowers were identified by coding them (in bud condition) with small black dots of ink on their pedicel. For each flower we recorded the date of opening and date of senescence. Senescence was defined when the corolla lost its lustrous look and had fallen off. The amount of floral resources (pollen and nectar) produced per flower was estimated. The average number of pollen grains produced per flower ( $\mathrm{n}=10$ ) was estimated using a haemocytometer (Dafni 1992). The number of ovules was counted directly by rupturing the ovary wall. To determine the nectar yield, 10 randomly selected flowers were bagged before anthesis and the nectar volume was measured using $20 \mu \mathrm{l}$ Hirschmann minicap calibrated capillary tubes. Stigma receptivity was measured using benzidine $-\mathrm{H}_{2} \mathrm{O}_{2}$ test (Dafni 1992), as well as pollen germination test. To perform in-vivo germination test for stigma receptivity, the selected hermaphrodite flowers ( $\mathrm{n}=20$ for each time interval) were emasculated before anthesis and bagged. Then the emasculated flowers were hand-pollinated with cross-pollen from other plants at $0,12,24,36,48,60,72,84$ and $96 \mathrm{~h}$ following flower opening. After $3 \mathrm{~h}$, the pollinated styles were removed from the flowers and fixed in FAA (1:1:8 v/v/v formalin: glacial acetic acid: $80 \%$ ethanol) solution. The styles were rinsed with distilled water and stained with $0.1 \%$ aniline blue solution. Then the stained styles were taken on a glass slide with glycerol and gently squashed with a cover slip. The preparations were then examined under optical microscope. Pollen viability at the time of anther dehiscence and later stages was estimated by staining method as well as in-vivo germination test. For staining purposes we used aqueous solution of iodine potassium iodide (Baker \& Baker 1979).

\section{Floral visitors}

Floral visitors were observed during different times of the day and night throughout its flowering period. The voucher specimens of insects were sent to entomologists for identification at Zoological Survey of India (ZSI), Kolkata. The number of each visitor was counted in all field observations and then relative abundance of different visitors was calculated as follows:

Relative abundance $(\%)=\frac{\text { Number of a visitor }}{\text { Total number of all visitors }} \times 100$

Foraging rate of the floral visitors was recorded in terms of the number of flowers visited per unit time (Free 1993). For each visitor, the type of visit (legitimate or illegitimate) and collected floral reward (nectar, pollen or tissue) were recorded. Furthermore, the efficiency of floral visitors in fruit/seed set was evaluated by single-visit pollination efficiency index (Spears 1983). Pollination efficiency index $(\mathrm{PE} i)$ was calculated as follows:

$$
\mathrm{PE} i=\frac{\mathrm{P} i-\mathrm{Z}}{\mathrm{U}-\mathrm{Z}}
$$

where $\mathrm{P} i$ is the mean number of seeds produced per flower after receiving a single visit of species $i$; $\mathrm{Z}$ is the mean number of seeds produced per flower which does not receive visitation; and $U$ is the mean number of seeds produced per flower by a plant population which exposed to unrestricted visitation.

We also calculated a combined parameter, relative pollinator service (RPS) for each floral visitor as follows:

$$
\operatorname{RPS}(\%)=\frac{\mathrm{RA} \times \mathrm{FR} \times \mathrm{PE} i}{\sum \mathrm{RA} \times \mathrm{FR} \times \mathrm{PE} i} \times 100
$$

where RA is the relative abundance of a visitor over the studied plant and FR is the foraging rate of the visitor. Based on the values of this parameter, we classified the floral visitors into four categories: primary pollinator (RPS $>20 \%$ ), important secondary pollinator $(10<\mathrm{RPS}<20 \%)$, secondary pollinator $(0<\mathrm{RPS} \leq 10 \%)$ and non-pollinator $(\mathrm{RPS}=0)$. Flower visiting groups were also classified into four categories: primary pollinating group (RPS > $50 \%$ ), important secondary pollinating group $(20<$ RPS $\leq 50 \%)$, secondary pollinating group $(0<\mathrm{RPS} \leq 20 \%)$ and nonpollinating group (RPS $=0)$.

\section{Breeding system}

To determine the breeding system, we carried out six pollination treatments and selected 100 flowers for each treatment. Those were (i) apomixis (emasculated flowers 
were bagged without pollination), (ii) autogamy (bagged the complete flower, no supplementary pollen), (iii) selfpollination using the same flower (flowers were hand pollinated with the pollen from the same flower), (iv) geitonogamy (flowers were hand-pollinated with pollen from other flowers of the same individual), (v) cross-pollination (flowers were hand pollinated with pollen from other individuals) and (vi) open-pollination (unbagged, no supplementary pollen). In case of selfing, geitonogamy and cross-pollination, pollen grains were transferred to the stigma of the 2nd day flower. The numbers of fruit set were counted for each treatment. Following Raduski et al. (2011), we measured the index of self-incompatibility (ISI) as follows:

$$
\text { ISI }=1-\frac{\text { relative selfed success }}{\text { relative outcrossed success }}
$$

Based on the ISI value, we classified the plant species out of the following three viz. (i) self-incompatibility (ISI $\geq 0.8$ ), (ii) partial self-incompatibility $(0.2<$ ISI $<0.8)$, and (iii) selfcompatibility $(\mathrm{ISI} \leq 0.2)$.

To determine pollination deficiency of the plant species within the study areas, we calculated a coefficient of pollination deficit (D) as follows:

\section{$\mathrm{D}=1-\frac{\text { Percentage of fruit set in open pollination system }}{\text { Percentage of fruit set in hand pollination system }}$}

Based on the value of $\mathrm{D}$, we categorized the studied plant species as one of the following classes: high pollination deficit $(\mathrm{D}>0.5)$, medium pollination deficit $(0.3 \leq \mathrm{D} \leq 0.5)$, low pollination deficit $(0.1<\mathrm{D} \leq 0.3)$, and negligible pollination deficit $(\mathrm{D}<0.1)$.

\section{Statistical analyses}

Statistical analyses of the data were conducted to obtain the arithmetic mean, standard deviation and confidence interval at 95\% level. One-way ANOVA followed by Duncan's multiple range test (DMRT) were used to analyze data and $\mathrm{P} \leq 0.05$ was considered statistically significant.

\section{RES U LT S \\ Floral ecology}

The initiation of flower buds was noticed during November. Flowering period was from the middle of December to last week of March. The flowering pattern is of cornucopia type. The inflorescence may carry a single flower or several flowers on axillary cymes. Both male and hermaphrodite flowers are produced on the same inflorescence. Some inflorescences also produced abnormal flowers and they did not open completely (Fig. 1). The ratio of hermaphrodite to male flowers was very high during early flowering phase (7.42 : 1). Then, the ratio gradually decreased with time (Fig. 2) and during late flowering time (last week of March) the ratio was minimal $(0.36: 1)$. Flower opening starts at any time between 7:00 and 15:00 $\mathrm{h}$ and completed by the second day. Initiation of opening was marked by the formation of slits between two petals. Longevity of the flower was 3-4 days.

Flowers are ebracteate, pedicillate and actinomorphic. Five minute $(4.5 \times 1 \mathrm{~mm})$ creamish-white sepals are united at base. The corolla is constituted with five petals (rarely four in number), with white inner side and pinkish white outer side. The dimensions of petals are significantly differed in between hermaphrodite and male flowers (length: $F_{1,38}=214.03, P<0.01$; breadth: $\left.F_{1,38}=18.74, P<0.01\right)$. Hermaphrodite flowers have larger petals $(23.22 \pm 0.99 \times$ $6.18 \pm 0.92 \mathrm{~mm})$ in comparison to male flowers $(19.68 \pm 0.44$ $\times 5.18 \pm 0.47 \mathrm{~mm})$. Both hermaphrodite and male flowers bear numerous stamens $(41.35 \pm 6.07$ and $32.45 \pm 2.95$ respectively) arranged in two whorls around the gynoecium. Anthers are two-celled, sagittate and basifixed. Filaments are thin and variable in length $(5-10 \mathrm{~mm})$. Filaments of the outer whorl stamens are larger than the inner whorl stamens. Each flower produced $9058.70 \pm 1627.94$ pollen grains. Carpels are many and syncarpous. The ovary is superior, green, and many chambered. The number of ovules per ovary was $73.20 \pm 6.27$. Style is green, thick and $7.70 \pm 0.48 \mathrm{~mm}$ in length. The stigma is capitate. The pollenovule ratio was $1176.45: 1$. Nectarines were present at the
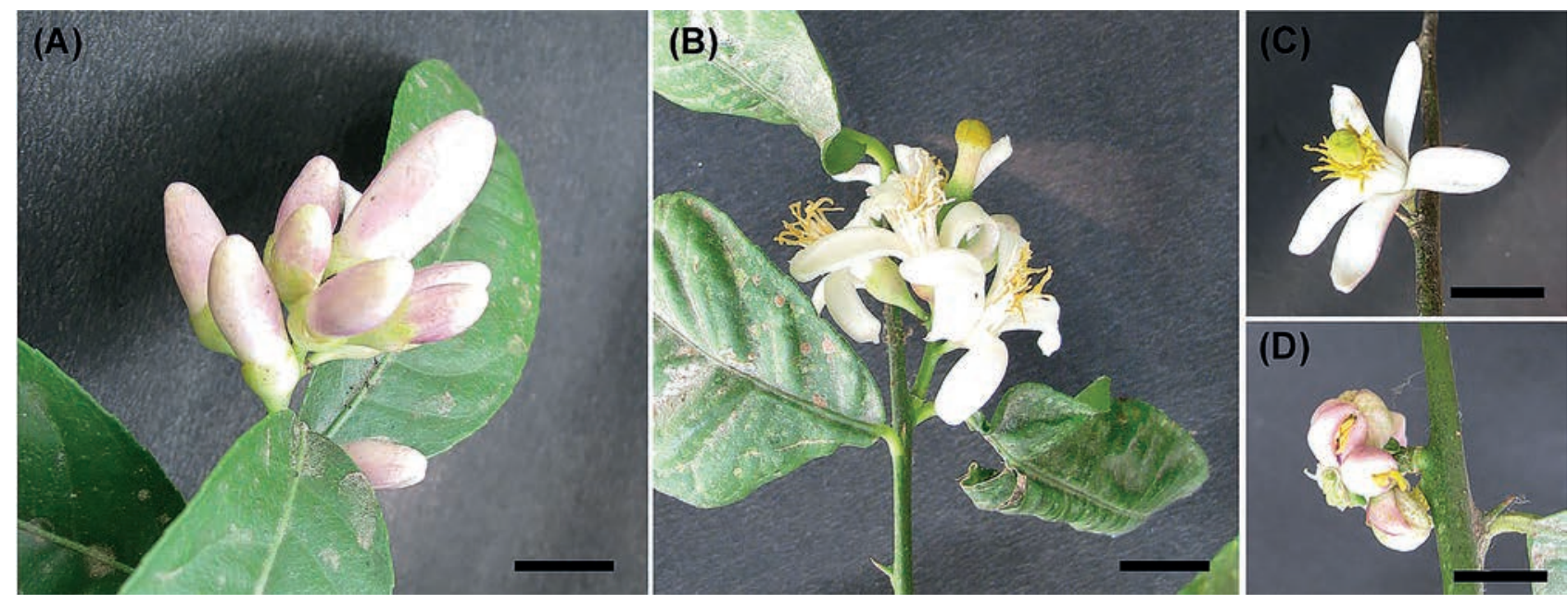

Figure 1 Flowers of Citrus $\times$ limon (L.) Osbeck. (A) - flower buds; (B) - inflorescence with many flowers, both hermaphrodite and male; (C) - inflorescence with single hermaphrodite flower; (D) - abnormal flowers. Scale bar - $10 \mathrm{~mm}$ 


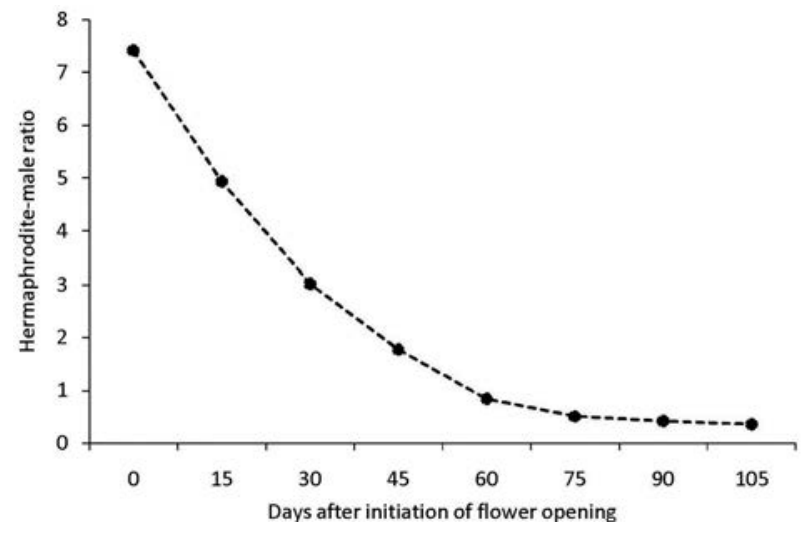

Figure 2 Hermaphrodite-male flowers ratio at different flowering time

base of ovary. The amount of nectar produced per flower was $24.97 \pm 6.07 \mu \mathrm{L}$.

Anther dehiscence starts before the completion of flower opening. Initiation of anther dehiscence takes place by the appearance of a longitudinal slit within the theca. Pollen grains remain viable up to $72 \mathrm{~h}$ on 4 th day. At the time of flower opening, most of the pollen grains $(88.83 \pm 5.87 \%)$ were viable. Then, viability was gradually decreased and at the time of initiation of senescence (on 4th day after flower opening) only a few pollen grains $(21.12 \pm 5.45 \%)$ took the stain which confirmed their viability. At the time of flower opening, the stigma was non-receptive. After 24 hours of flower opening (i.e. on 2 nd day), the stigma accrues its true receptivity which was supported by both $\mathrm{H}_{2} \mathrm{O}_{2}$ test and in-vivo pollen germination test. The stigma retained its receptivity up to $84 \mathrm{~h}$ on the 4th day after flower opening. During this period each hermaphrodite flower passes through two sexual phases: male and bisexual phase. Flower opening started with male phase which lasts for 24 hours, followed by bisexual phase.

\section{Floral visitors}

A total of 10 insect species were observed to visit the flower of C. $\times$ limon (Fig. 3, Table 1). Among those, 6 were Hymenopterans, three were Dipteran flies and one was Lepidopteran butterfly. The most frequently visited floral insects were Stomorbina discolor (relative abundance $19.81 \%$ ),
Episyrphus balteatus (relative abundance $17.92 \%$ ), and Halictus sp. (relative abundance $16.89 \%$ ). Hymenoperan members (especially Xylocopa fenestrata and Apis dorsata) have greater foraging rate than the butterflies and flies (Table 1). Honey bees, solitary bees and carpenter bees were legitimate visitors and collected both nectar and pollen. In general, members of butterflies and Dipteran flies were illegitimate visitors of the flower and acted as nectar thief and pollen thief, respectively. Occasionally, Stomorbina discolor and Stomorbina obsoleta consumed the stigmatic secretion and serve as legitimate visitors. The values of Pollination efficiency index (PE $\imath$ ) were high in Nomia sp. (0.79), Halictus sp. (0.76), and Xylocopa fenestrata (0.54). The value of relative pollinator service (RPS) was the highest in Halictus sp. (33.05\%), followed by Nomia sp. (21.47\%), Apis dorsata $(16.95 \%)$, and Xylocopa fenestrata $(13.69 \%)$. According to the value of relative pollinator service, primary pollinator of the plant species was Halictus sp. and Nomia sp. The honey bee Apis dorsata and carpenter bee Xylocopa fenestrata were also acted as important secondary pollinator. As group consideration, the lemon cultivar is primarily pollinated by solitary bees.

\section{Breeding system}

Emasculated flowers did not form fruits. The remaining five treatments (autonomous selfing, selfing with same flower pollen, geitonogamy, crossed and open-pollination) led to fruit formation (Table 2). The fruit set percentages among these five treatments were significantly differed $\left(F_{4,45}=23.95, P<0.01\right)$. The highest fruit set obtained in cross-pollinated treatment $(60 \pm 10.54 \%)$ and the lowest in case of autonomous selfing $(12 \pm 10.33 \%)$. Fruit set in open condition was significantly lower $(27 \pm 11.60 \%)$ in comparison to manually pollinated fruit sets. The index of self-incompatibility (ISI) was very low (0.18), suggesting that the plant behaved as a self-compatible species. According to the value of coefficient of pollination deficit $(\mathrm{D}=0.49)$, the Gandharaj lemon showed medium pollination deficit at the study sites. Furthermore, pre-mature fruit abortion was very high in all the pollination treatments (Table 2). Spontaneous automagy and open-pollination treatments have comparatively higher rate of fruit abortion than manual pollination treatments.

Table 1. Floral visitors of Citrus $\times$ limon $(\mathrm{LV}-$ legitimate visitor, NT - nectar thief, PT - pollen thief, PE $i$ - pollination efficiency index, RPS - relative pollinator service).

\begin{tabular}{|c|c|c|c|c|c|c|}
\hline Visitors & $\begin{array}{c}\text { Relative } \\
\text { abundance (\%) }\end{array}$ & $\begin{array}{c}\text { Foraging } \\
\text { rate }\end{array}$ & $\begin{array}{l}\text { Foraging } \\
\text { strategy }\end{array}$ & Resource & PE $i$ & RPS ( $\%)$ \\
\hline \multicolumn{7}{|l|}{ Diptera } \\
\hline Episyrphus balteatus & 17.92 & 0.35 & PT & Pollen & - & - \\
\hline Stomorbina discolor & 19.81 & 0.20 & PT, LV(rare) & Pollen, exudates of stigma & 0.06 & 0.22 \\
\hline Stomorbina obsoleta & 11.32 & 0.20 & PT, LV (rare) & Pollen, exudates of stigma & 0.04 & 0.08 \\
\hline \multicolumn{7}{|l|}{ Hymenoptera } \\
\hline Apis cerana & 3.77 & 3.10 & LV & Nectar, pollen & 0.46 & 4.92 \\
\hline Apis dorsata & 10.38 & 5.10 & LV & Nectar, pollen & 0.35 & 16.95 \\
\hline Apis florea & 6.13 & 3.90 & LV & Nectar, pollen & 0.44 & 9.62 \\
\hline Halictus sp. & 16.98 & 2.80 & LV & Nectar, pollen & 0.76 & 33.05 \\
\hline Nomia sp. & 8.49 & 3.50 & $\mathrm{LV}$ & Nectar, pollen & 0.79 & 21.47 \\
\hline Xylocopa violacea & 3.30 & 8.40 & LV & Nectar, pollen & 0.54 & 13.69 \\
\hline \multicolumn{7}{|l|}{ Lepidoptera } \\
\hline Hypolimnas sp. & 1.89 & 3.30 & NT & Nectar & - & - \\
\hline
\end{tabular}



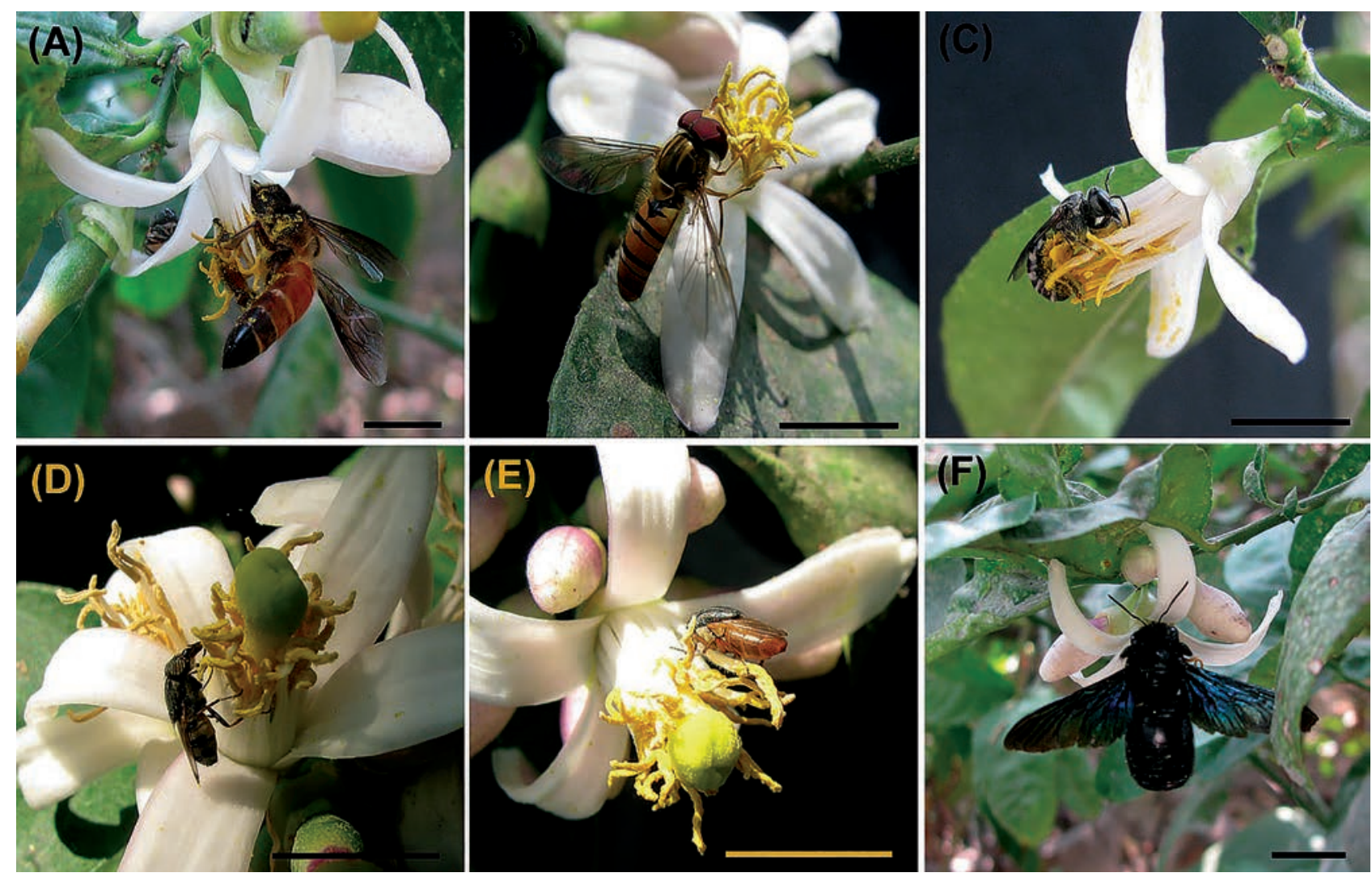

Figure 3 Floral visitors of Citrus $\times$ limon (L.) Osbeck. (A) - Apis dorsata; (B) - Episyrphus balteatus; (C) - Halictus sp.; (D) - Stomorbina discolor; (E) - Stomorbina obsoleta; (F) - Xylocopa fenestrata. Scale bar - $10 \mathrm{~mm}$

\section{DISCUSSION}

The flowering time of Gandharaj cultivar is from winter to spring, like that of other species of lemon cultivated in India (Karmakar 2013). Floral morphology is also similar with the typical Citrus species. However, presence of male flowers and abnormal flowers in addition to hermaphrodite flowers is documented for this plant. Two types of flowers (hermaphrodite and staminate) were also observed in Citrus sinensis (Kumatkar et al. 2016). However, Ribeiro et al. (2016) reported the presence of infertile ovary with terminal inclusion of stylet and undivided stigma. The ratio of hermaphrodite to male flowers was higher during early to mid flowering phase and lesser during the later half of the flowering stage. Therefore, it could be considered as a gentle factor which provides a lower yield. The pollen-ovule ratio was slightly lower $(1176.45: 1)$ in comparison to Citrus sinensis
(Ribeiro et al. 2016). Pollen-ovule ratio is an indicator of the reproductive system of plants (Cruden 1977). According to the classification of Cruden (1977), the plant species would be of facultative xenogamous type. Flower longevity ranged from 3 to 4 days. The greater longevity of flowers enhances floral display size and the reproductive fitness of the plant species. The bisexual flowers showed temporal separation of male and female functions with two distinct phages i.e. male, and bisexual. The present species exhibits protandry which is more common in angiosperm in comparison to protogyny (Routley et al. 2004). However, the mechanism remains less effective here for cross-pollination. Because of greater floral display size, there is huge risk for visiting insects foraging from one flower to another on the same plant leading to geitonogamous selfing and greatly reduced pollen export.

Table 2. The effect of pollination treatment on fruit set of Citrus $\times$ limon.

\begin{tabular}{lcccccc}
\hline \multirow{2}{*}{ Pollination treatment } & \multicolumn{3}{c}{ Fruit set (\%) } & \multicolumn{2}{c}{ Fruit abortion (\%) } \\
\cline { 2 - 7 } & Mean & S.D. & CI (95\%) & Mean & S.D. & CI (95\%) \\
\hline Apomixis & $0^{\mathrm{e}}$ & 0 & 0 & - & - & - \\
Spontaneous autogamy & $12^{\mathrm{d}}$ & 10.33 & $4.61-19.30$ & $59.52^{\mathrm{a}}$ & 44.99 & $17.92-101.13$ \\
Self-pollination using the same flower & $48^{\mathrm{b}}$ & 13.17 & $38.58-57.42$ & $36.52^{\mathrm{ab}}$ & 13.12 & $27.14-45.91$ \\
Geitonogamy & $51^{\mathrm{b}}$ & 16.63 & $39.10-62.90$ & $35.11^{\mathrm{ab}}$ & 9.75 & $28.13-42.08$ \\
Cross-pollination & $60^{\mathrm{a}}$ & 10.54 & $52.46-67.54$ & $32.89^{\mathrm{b}}$ & 15.29 & $21.96-43.83$ \\
Open-pollination & $27^{\mathrm{c}}$ & 11.60 & $18.71-35.29$ & $50.83^{\mathrm{ab}}$ & 31.54 & $28.27-73.39$ \\
\hline
\end{tabular}

Means in the column followed by same letters do not differ significantly by DMRT at 5\%, CI confidence interval, S.D. standard deviation. 
The plant produced significant amount of floral rewards (nectar and pollen) and attracted several Hymenopteran, Dipteran and Lepidopteran members. Some of those (Apis cerana, Apis dorsata, Apis florea, Episyrphus sp., and Halictus sp.) were common to other Citrus species in West Bengal (Karmakar 2013). The documentation of honey bees as visitor of Citrus spp. was revealed from different regions of the world (Malerbo-Souza et al. 2003, Nascimento et al. 2011, Ribeiro et al. 2016). In this study, we used a new index called 'relative pollinator service' (RPS) in addition to pollination efficiency index to determine the importance of floral visitors on reproductive success of plant species. We assumed that the relative pollinator service is the more reliable parameter than pollination efficiency index, because several important factors like relative abundance, foraging rate and pollination efficiency index all were considered under RPS. In regards to the values of RPS, we considered the plant species as solitary bee pollinated. However, the phenomenon of honey bee pollination for Citrus spp. was well established (Bodlan \& Armad 2015, Ribeiro et al. 2016). Therefore, through the pollination services, Hymenopteran members increase the reproductive success of the plant species. On the other hand, most of the Dipteran flies acted as pollen thieves and Lepidopteran butterflies were performed as nectar thieves, and thus, reduces reproductive success of Gandharaj lemon.

Very low value of self-incompatibility index (0.08) entails the plant species as self-compatible. Self-compatibility also reported for different Citrus species like C. natsudaidai ( $\mathrm{Ngo}$ 2001), C. reticulata (Yamamoto et al. 2006), and C. sinensis (Yamamoto et al. 2006). Gandharaj lemon cultivar showed medium pollinator deficit within the study areas which is an important factor for low yield of the crop. In addition, the cultivar showed high rate of pre-mature fruit abortion in all the pollination treatments including open-pollinated systems. This phenomenon was quite common in different Citrus species (Agustí et al. 1982, Mehouachi et al. 1995). Greater abscission of reproductive structures was happened due to defoliation (Mehouachi et al. 1995) or higher flowering intensity (Agustí et al. 1982). However, exact cause of the high rate of pre-mature fruit abortion in this cultivar is yet to be identified and needs further research works.

\section{CONCLUSION}

Gandharaj lemon cultivar produces protandric hermaphrodite flowers and male flowers with large floral display size and considerable amount of floral rewards. As a result, diverse array of insects (honey bees, solitary bees, carpenter bees, flies and butterflies) visited the flowers. Regarding the legitimacy of the visitors, honey bees, solitary bees and carpenter bees were legitimate ones. However, in open-pollination system the cultivar showed medium pollination deficit $(\mathrm{D}=0.49)$ within our study areas. In addition, high rate of pre-mature fruit abortion lead to low fruit yield of Gandharaj lemon in West Bengal.

\section{ACKNOWLEDGEMENTS}

We are thankful to authorities of Vidyasagar University for providing necessary laboratory facilities. Thanks are also given to UGC due to partial funding through DRSSAP phase-II [No. F.5-2/2018/DRS-II(SAP-II)]. We are also grateful to Entomology section, Zoological Survey of India for identification of the floral visitors.

\section{LITERAT URE CITED}

Agustí, M., F. García-Marí \& J.L. Guardiola 1982. The influence of flowering intensity on the shedding of reproductive structures in sweet orange. Scientia Horticulturae 17:343-352.

Ashman, T.L., T.M. Knight, J.A. Steets, P. Amarasekare, M. Burd, D.R. Campbell, M.R. Dudash, M.O. Johnston, S.J. Mazer, R.J. Mitchell, M.T. Morgan \& W.G. Wilson 2004. Pollen limitation of plant reproduction: ecological and evolutionary causes and consequences. Ecology 85:2408-2421.

Baker, H.G. \& I. Baker 1979. Starch in angiosperm pollen grains and its evolutionary significance. American Journal of Botany 66:591-600.

Bodlan, I. \& M. Armad 2015. Insect pollinators visiting citrus (Citrus limon) and avocardo (Persea americana) fruit trees. Asian Journal of Agriculture and Biology 3:23-27.

Cruden, R.W. 1977. Pollen-ovule ratios: a conservative indicator of breeding systems in flowering plants. Evolution $31: 32-46$.

Dafni, A. 1992. Pollination Ecology: A Practical Approach. Oxford University Press, Oxford.

Elzinga, J.A., A. Atlan, A. Biere, L. Gigord, A.E. Weis \& G. Bernasconi 2007. Time after time: flowering phenology and biotic interactions. Trends in Ecology and Evolution 22: 432-439.

Erickson, L.C. \& B.L. Brannaman 1960. Abscission of reproductive structures and leaves of orange trees. Proceeding of the American Society for Horticultural Science 75:222-229.

Free, J.B. 1993. Insect Pollination of Crops. 2nd edition. Academic Press, London.

Gaines-Day, H.R. \& C. Gratton 2015. Biotic and abiotic factors contribute to cranberry pollination. Journal of Pollination Ecology 15:15-22.

Gentry, A.H. 1974. Flowering phenology and diversity in tropical Bignoniaceae. Biotropica 6:64-68.

Goldschmidt, E.E. \& S.P. Monselise 1977. Physiological assumptions toward the development of a citrus fruiting model. Proceeding of the International Society of Citriculture 2: 668-672.

Hilgeman, R.H., J.A. Dunlap \& G.C. Sharples 1967. Abscission of reproductive structures and leaves of orange trees. Proceedings of the American Society for Horticultural Science 75:222-229.

Karmakar, P. 2013. Pollination biology of Citrus aurantiifolia (Christm.) Swingle: a medicinally important fruit plant. International Journal of Innovative Research and Development 2: 138-142.

Koo R.C.J. 1967. Importance of moisture control in citrus groves. Citrus World 13:16.

Kudo, G. 2006. Flowering phonologies of animal-pollinated plants: reproductive strategies and agents of selection. In: Ecology and Evolution of Flowers, (L.D. Harder \& S.C.H. Barrett, eds.), pp. 139-158. Oxford University Press, New York.

Kumatkar, R.B., A.K. Godara \& V.K. Sharma 2016. Studies on floral biology and breeding behavior of sweet orange 
[Citrus sinensis (L.) Osbeck.]. The Bioscan 11:543-546.

Malerbo-Souza, D.T., R.H. Nogueira-Couto \& L.A. Couto 2003. Pollination in orange sweet crop (Citrus sinensis L. Osbeck, var. pera-rio). Brazilian Journal of Veterinary Research and Animal Science 40:237-242.

Mehouachi, J., D. Serna, S. Zaragoza, M. Agusti, M. Talon \& E. Primo-Millo 1995. Defoliation increases fruit abscission and reduces carbohydrate levels in developing fruits and woody tissues of Citrus unshiu. Plant Science 107:189-197.

Monselise, S.P. 1986. Citrus. In: Handbook of fruit set and development, (S.P. Monselise, ed.), pp. 87-108. CRC Press, Boca Raton.

Nascimento, E.T., R. Pérez-Malf, R.A. Guimarães \& M.A. Castellani 2011. Diversity of flowers visiting bees of Citrus in Salinas, state of Minus Gerais. Revista Brasileira de Fruticultura 33: 111-117.

Ngo, B.X. 2001. Study on the self-incompatibity in Citrus (Rutaceae) with special emphases on the pollen tube growth and allelic variation. Ph. D. Thesis. Kyushu University, Fukuoka.

Ollerton, J., R. Winfree \& S. Tarrant 2011. How many flowering plants are pollinated by animals? Oikos 120:321-326.
Opler, P.A., H.G. Baker \& G.W. Frankie 1980. Plant reproductive characteristics during secondary succession in Neotropical lowland forest ecosystems. Biotropica 12:40-46.

Raduski, A.R., E.B. Haney \& B. Igic 2011. The expression of self-incompatibility in angiosperms is bimodal. Evolution 66:1275-1283.

Ribeiro, G.S., E.M. Alves \& C.A.L. Carvalho 2016. Biology of pollination of Citrus sinensis variety 'Pera Rio'. Revista Brasileira de Fruticultura 39:e-033.

Routley, M.B., R.I. Berlin \& B.C. Husband 2004. Correlated evolution of dichogamy and self-incompatibility: A phylogenetic approach. International Journal of Plant Sciences 165:983-993.

Spears, E.E. 1983. A direct measure of pollinator effectiveness. Oecologia 57:196-199.

Yamamoto, M., T. Kubo \& S. Tominaga 2006. Self- and cross-incompatibility of various Citrus accessions. Journal of the Japanese Society for Hortcultural Science 75:372-378.

Zucconi, F., S.P. Monselise \& R. Goren 1978. Growth abscission relationships in developing orange fruit. Scientia Horticulturae 9:137-146. 